\title{
Cluster analysis of variability of key parameters of the economic environment in the framework of diffusion of blockchain technologies
}

\author{
Marat Safiullin ${ }^{1,2}$, Leonid Elshin ${ }^{1,2,3}$, and Aliya Abdukaeva ${ }^{1,2,3, *}$ \\ ${ }^{1}$ Kazan Federal University, Kazan, Russia \\ ${ }^{2}$ Center of Advanced Economic Research in the Academy of Sciences of the Republic of Tatarstan, \\ Kazan, Russia \\ ${ }^{3}$ Kazan National Research Technological University, Kazan, Russia
}

\begin{abstract}
Prospects for the development of the national economy in the context of integration of blockchain technologies into the system of economic processes indicate the need to develop methods and algorithms for a formalized assessment of their impact on the key parameters of socioeconomic dynamics. Meanwhile, if in the scientific and expert space, although it is extremely rare, but still one can find works devoted to certain aspects of this scientific and methodological problem, then, unfortunately, it should be stated that the study of the impact of the technologies under study on certain sectors of the economy does not occur in information-analytical and scientific spaces at all. Unfortunately, the methods of empirical study of the influence of blockchain technologies on the parameters of economic development at the current time not only have not found their consolidated solution, but are completely characterized by fragmentation and patchiness. This study is an attempt to strengthen the positions of formalized approaches to the study of the scientific and practical problem. The paper proposes an algorithm for studying the dynamics of the gross value added of the sectors of the Russian economy through the prism of a possible transformation of the key parameters of the functioning of the financial and real sectors of the economy as a result of the diffusion of blockchain technologies. Relying on the hypotheses put forward, cointegration models were built for the studied types of economic activity, which make it possible to identify the contribution of exogenous factors, corrected under the pressure of penetration of distributed data storage technologies into the economic environment, on the degree of added value growth. This, in turn, made it possible to carry out a cluster analysis of the studied sectors of the economy in terms of their level of sensitivity to institutional transformations caused by the integration of blockchain technologies into the economic environment.
\end{abstract}

* Corresponding author: Aliya.Abdukaeva@tatar.ru 


\section{Introduction}

It should be noted that in the conditions of the gaining momentum of the fourth industrial revolution, it is increasingly possible to observe the active integration into the system of economic relations of new, progressive forms of organization of models of socio-economic development. Among them, undoubtedly, it is necessary to include blockchain technologies that have been intensively penetrating the socioeconomic environment in recent years and falling into the "orbit" of attention of many experts and scientists. Meanwhile, with regret, we have to state that, despite the progressive interest on the part of the expert and scientific community in distributed data storage technologies and the problems of studying their impact on the development of the national economy and its individual sectors, there is both disunity of views on the solution of the question posed, and lack of unified approaches to a formalized assessment of possible generated opportunities and risks. As a rule, existing works devoted to the problems of researching the impact of blockchain technologies on economic dynamics are limited either by qualitative characteristics, or implemented through the prism of expert assessments, as well as reasoning of a general logical order. At the same time, in the overwhelming majority of cases, the positions of authors, both Russian and foreign, are inclined to believe that studies of this kind of issues are extremely relevant, significant from a practical and scientific point of view, and require the development of an appropriate methodological apparatus [1-8].

In this regard, taking into account the very high interest in the problems posed, there is a need to develop methodological solutions that provide the process of substantiating the influence of distributed data storage technologies on the possible growth dynamics of individual sectors of the national economy. The solution to this problem will allow not only to move from qualitative assessments to formalized ones based on the use of special methods of economic and mathematical modeling, but also to form a foundation for the creation and development of the theory of blockchain economics.

\section{Research methodology}

It is important to emphasize that the development of economic sectors is characterized by heterogeneity and differentiation, both in terms of dynamics and in terms of their sensitivity to transformations in the external and internal environment. The integration of blockchain technologies into the economic environment of the national economic system will undoubtedly affect the key parameters of the development of economic activities in the same uneven and disproportionate way.

Developing this research paradigm, the authors make an attempt to develop an appropriate methodological toolkit, the testing of which is implemented on the example of certain types of economic activity corresponding to the OKVED codes (Russian National Classifier of Economic Activities).

The work used quarterly data for the period from 2008 to 2019 from official sources [9]. The calculations were carried out using the Eviews statistical package. Table 1 shows the variables of the developed model, their symbols and data sources. The choice of these exogenous factors used in the construction of the corresponding models is due to their priority in terms of sensitivity to the penetration of blockchain technologies into the economic environment $[10,11]$. 
Table 1. Description of the variables of the developed model.

\begin{tabular}{|l|c|c|}
\hline Variable & Designation & Data source \\
\hline \multicolumn{2}{|c|}{ Dependent } \\
\hline $\begin{array}{l}\text { Gross value added (in the } \\
\text { context of each analyzed sector } \\
\text { of the Russian economy), } \\
\text { billion rubles }\end{array}$ & GVA & Rosstat \\
\hline \multicolumn{2}{|c|}{ Undependent } \\
\hline $\begin{array}{l}\text { Stock market trading volume, } \\
\text { billion rubles }\end{array}$ & $V_{\text {trades }}$ & $\begin{array}{c}\text { Moscow } \\
\text { Exchange }\end{array}$ \\
\hline $\begin{array}{l}\text { Money transfers through the } \\
\text { payment system of the Bank } \\
\text { of Russia using translation } \\
\text { services / settlement systems, } \\
\text { billion rubles }\end{array}$ & $V_{\text {transactions }}$ & $\begin{array}{c}\text { Central Bank of } \\
\text { Russia }\end{array}$ \\
\hline $\begin{array}{l}\text { Total profit / loss of operating } \\
\text { credit institutions, million } \\
\text { rubles }\end{array}$ & $V_{\text {finresults }}$ & $\begin{array}{c}\text { Central Bank of } \\
\text { Russia }\end{array}$ \\
\hline
\end{tabular}

An important methodological aspect that predetermined the order of constructing a model is that in the case of studying stochastic time series, the use of traditional methods of correlation-regression analysis can lead to problems expressed in bias, inconsistency and inefficiency of the estimates obtained. This means that such a model may be unsuitable for further analysis and forecasting.

The study of dependencies between financial (stochastic) time series can be carried out using the method of cointegration analysis, where the cointegration equation has the form:

$$
\begin{gathered}
\Delta Y_{t}=\rho Y_{t-1}+\sum_{i=1}^{m-1} T_{i} \Delta Y_{t-i} \varphi X_{t}+\varepsilon_{t} \\
\rho=\sum_{i=1}^{n} A_{i}-I \text { and } T_{i}=-\sum_{j=i+1}^{n} A_{j} .
\end{gathered}
$$

In a concentrated form, Figure 1 shows a graphical interpretation of the algorithm for assessing the impact of diffusion of blockchain technologies on the development of sectors of the national economy. 
Stage 1 . The choice of factors generating an increase in GVA as a result of the diffusion of blockchain technologies.

Data collection

Stage 2. Elimination of seasonal components for time series characterizing the dynamics of changes in the analyzed factor

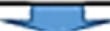

Stage 3. Checking the stationarity of time series

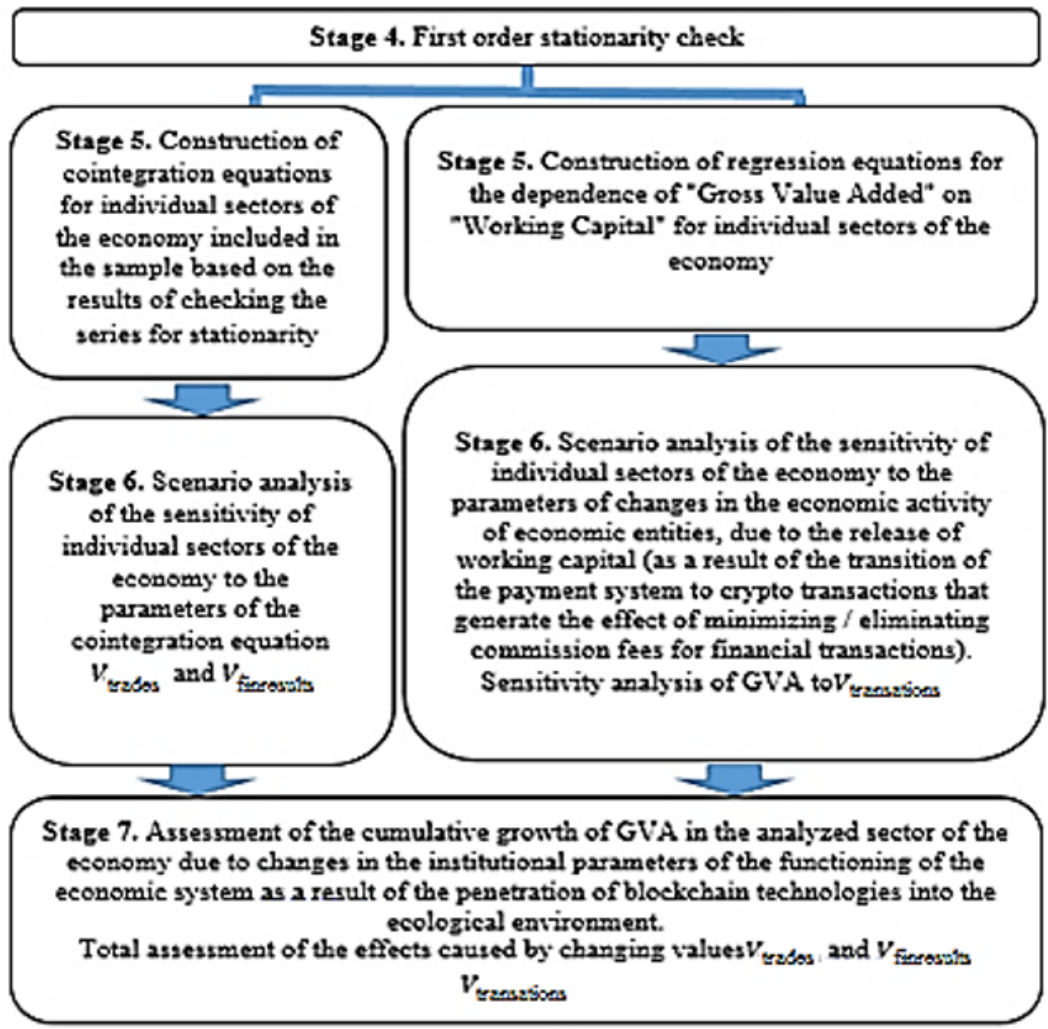

Figure 1. Graphical interpretation of the algorithm for assessing the impact of diffusion of blockchain technologies on the development of sectors of the national economy.

\section{Research results}

According to the results of testing the analyzed time series for their stationarity, the integrated series of the first order are the series characterizing the development parameters of the following sectors of the Russian economy:

- agriculture,

- mining,

— manufacturing industries,

- trade,

- financial and insurance activities,

- transportation and storage,

— public administration and military security; social security, 
- activities in the field of health care and social services.

The identified sectors of the economy are suitable for applying the method of cointegration research and formed the basis for further iterations.

In accordance with the proposed research algorithm (Figure 2), for each type of economic activity that fell into the investigated, according to the results of evaluating the stationarity of the series, the sample, the corresponding cointegration equations are constructed. The results are shown in Table 2.

Table 2. Results and data of the statistical significance of the cointegration equations in the context of the analyzed types of economic activities included in the studied sample.

\begin{tabular}{|c|c|c|c|c|}
\hline & \multicolumn{3}{|c|}{$\begin{array}{c}\text { Cointegration equation } \\
\text { parameters } \\
\end{array}$} & \multirow[b]{2}{*}{$R^{2}$} \\
\hline & $\begin{array}{c}\text { Stock } \\
\text { marke } \\
\mathbf{t} \\
\text { tradin } \\
\mathbf{g} \\
\text { volum } \\
\text { e }\end{array}$ & $\begin{array}{c}\text { The } \\
\text { number of } \\
\text { money } \\
\text { transfers } \\
\text { made } \\
\text { through } \\
\text { the } \\
\text { payment } \\
\text { system of } \\
\text { the Bank } \\
\text { of Russia, } \\
\text { million } \\
\text { rubles } \\
\end{array}$ & $\begin{array}{c}\text { Balanced } \\
\text { financial } \\
\text { result of } \\
\text { organizat } \\
\text { ions' } \\
\text { activities, } \\
\text { billion } \\
\text { rubles }\end{array}$ & \\
\hline agriculture & $\begin{array}{c}0.0008 \\
52\end{array}$ & 0.652552 & 0.04299 & 0.79 \\
\hline mining & $\begin{array}{c}0.1408 \\
68\end{array}$ & 1.844097 & 0.300956 & 0.7 \\
\hline $\begin{array}{l}\text { manufacturing } \\
\text { industries }\end{array}$ & $\begin{array}{c}0.0611 \\
63\end{array}$ & 7.250821 & 0.155 & 0.80 \\
\hline trade & $\begin{array}{c}- \\
0.0033 \\
55\end{array}$ & 5.800934 & 0.070829 & 0.87 \\
\hline $\begin{array}{l}\text { financial and } \\
\text { insurance activities }\end{array}$ & $\begin{array}{c}0.0348 \\
93 \\
\end{array}$ & 0.472347 & 0.047427 & 0.76 \\
\hline $\begin{array}{l}\text { transportation and } \\
\text { storage }\end{array}$ & $\begin{array}{c}0.0008 \\
03 \\
\end{array}$ & 0.635689 & 0.005392 & 0.62 \\
\hline $\begin{array}{l}\text { public administration } \\
\text { and military security; } \\
\text { social security }\end{array}$ & 0.014 & 0.07 & 0.007 & 0.75 \\
\hline $\begin{array}{l}\text { activities in the field } \\
\text { of health and social } \\
\text { services }\end{array}$ & $\begin{array}{c}0.0041 \\
77\end{array}$ & 0.637559 & 0.009911 & 0.84 \\
\hline
\end{tabular}

All the constructed equations included in the sample have a high coefficient of determination (R-squared), which indicates their statistical significance.

In accordance with the data published earlier by the authors $[10,11]$, the possible effects caused by the adjustment of the analyzed factors ( $V_{\text {trades }}$ and $V_{\text {finresults, }} \mathrm{V}_{\text {transactions }}$ ) as a result of the penetration of blockchain technologies into the system of economic relations are shown in Table 3. 
Table 3. Possible effects for the national economy of the Russian Federation caused by the adjustment of the studied factors $\left(\mathrm{V}_{\text {finresults, }} \mathrm{V}_{\text {trades, }}, \mathrm{V}_{\text {transactions }}\right)$ as a result of the penetration of blockchain technologies into the system of economic relations.

\begin{tabular}{|c|l|l|}
\hline No & $\begin{array}{l}\text { The exogenous factor of the } \\
\text { cointegration model }\end{array}$ & $\begin{array}{l}\text { Expected, in } \\
\text { accordance with } \\
\text { the scenario } \\
\text { analysis, increase } \\
\text { in the factor value, } \\
\text { in billion rubles. }\end{array}$ \\
\hline 1 & $\begin{array}{l}\text { V finresults - the total amount of } \\
\text { profit / loss received by } \\
\text { operating credit institutions }\end{array}$ & $\begin{array}{l}+88.5 \text { per year; } \\
\text { 22.125 average } \\
\text { quarter }\end{array}$ \\
\hline 2 & $\begin{array}{l}\text { Vtrades - the total amount of } \\
\text { profit / loss received by } \\
\text { operating credit institutions }\end{array}$ & $\begin{array}{l}+ \text { 462.61 on } \\
\text { average per quarter }\end{array}$ \\
\hline 3 & $\begin{array}{l}\text { Increase in working capital, } \\
\text { intensification of business } \\
\text { activity (effect of 1 factor } \\
\text { Vtransactions) }\end{array}$ & $\begin{array}{l}+128.0 \text { per year } \\
\text { (baseline scenario } \\
1, \text { Table 9) }\end{array}$ \\
\hline
\end{tabular}

The following is a sequence of calculations assessing the level of growth in gross value added as a result of the penetration of blockchain technologies into the national economy, as applied to a specific sector of the economy, was carried out on the basis of the following sequence of iterations (for example, the type of economic activity "Agriculture"):

1. Based on the data of the scenario analysis of the exogenous factors of the cointegration model $V_{\text {finresults }}$ and $V_{\text {trades }}$ in accordance with the previously calculated effects (Table 3 ), the sensitivity of the gross value added of the studied sector to changes in the analyzed parameters is determined.

2. To determine the parameter assessing the impact of the transformation of the payment system as a result of its transition to crypto transactions, a separate regression equation is constructed, where the GVA of the studied sector of the economy acts as an endogenous variable, and its working capital (in billion rubles) as an exogenous variable.

Table 4. Assessment of the impact of blockchain technologies on the parameters of gross value added (GVA) growth in the context of the studied set of sectors of the Russian economy, \%.

\begin{tabular}{|l|l|l|}
\hline \multicolumn{1}{|c|}{ Economic activity } & \multicolumn{1}{|c|}{$\begin{array}{c}\text { GVA growth } \\
\text { per year, \% }\end{array}$} & $\begin{array}{c}\text { GVA growth } \\
\text { per year, billion } \\
\text { rubles }\end{array}$ \\
\hline agriculture & 0.24 & 3.1 \\
\hline mining & 2.16 & 73.8 \\
\hline $\begin{array}{l}\text { manufacturing } \\
\text { industries }\end{array}$ & 0.87 & 32.9 \\
\hline trade & 0.0023 & 0.1 \\
\hline $\begin{array}{l}\text { financial and insurance } \\
\text { activities }\end{array}$ & 1.7 & 18.1 \\
\hline $\begin{array}{l}\text { transportation and } \\
\text { storage }\end{array}$ & 0.17 & 2.4 \\
\hline $\begin{array}{l}\text { public administration } \\
\text { and military security; } \\
\text { social security }\end{array}$ & 0.58 & 9.3 \\
\hline $\begin{array}{l}\text { activities in the field of } \\
\text { health and social } \\
\text { services }\end{array}$ & 0.43 & 2.7 \\
\hline
\end{tabular}




\section{Discussion of the results}

The obtained results, revealing the peculiarities of the influence of the penetration of blockchain technologies into the system of economic and operational processes of the national economy, form the basic foundations for conducting derivative forms of analysis, including clustering the studied types of economic activities by the type of their response to the penetration of distributed data storage technologies into the economic environment.

In accordance with the rules of statistical clustering, below are the main results of this type of work. The research was carried out on the basis of the use of hierarchical cluster analysis. When carrying out calculations and assessments, the information-automated package SPSS was used.

The preliminary results of the calculations made it possible to determine the number of enlarged groups (clusters) with similar characteristics, revealing the peculiarities of the influence of the analyzed three effects (growth of business activity as a result of the release of working capital; socialization of access channels to stock markets and growth of financial results of credit institutions) caused by "blockchainization" of national economic system (Figure 3).

The initial data of the parameters (factors) used for clustering the analyzed set of sectors of the national economy are presented in Table 5.

Table 5. Values of the factors used in the framework of cluster analysis aimed at determining homogeneous sectors of the economy by the degree of response to GVA growth as a result of diffusion of blockchain technologies.

\begin{tabular}{|c|c|c|c|c|}
\hline \multirow[b]{2}{*}{$\begin{array}{l}\text { Economic } \\
\text { activity }\end{array}$} & \multicolumn{4}{|c|}{ GVA growth per year, billion rubles } \\
\hline & $\begin{array}{c}V_{\text {finresults }} \\
\text { total profit } \\
\text { / loss } \\
\text { received } \\
\text { by } \\
\text { operating } \\
\text { credit } \\
\text { institutions }\end{array}$ & $\begin{array}{c}V_{\text {trades }}- \\
\text { stock } \\
\text { market } \\
\text { volume }\end{array}$ & $\begin{array}{c}\text { Increase in } \\
\text { working } \\
\text { capital, } \\
\text { revitalization } \\
\text { of business } \\
\text { activity }\end{array}$ & TOTAL \\
\hline agriculture & 0.95 & 0.39 & 1.79 & 3.1 \\
\hline mining & 6.65 & 65.16 & 1.98 & 73.8 \\
\hline $\begin{array}{l}\text { manufacturing } \\
\text { industries }\end{array}$ & 3.43 & 28.29 & 1.15 & 32.9 \\
\hline trade & 1.567 & -1.55 & 0.065 & 0.1 \\
\hline $\begin{array}{l}\text { financial and } \\
\text { insurance } \\
\text { activities }\end{array}$ & 1.05 & 16.14 & 0.86 & 18.1 \\
\hline $\begin{array}{l}\text { transportation } \\
\text { and storage }\end{array}$ & 1.95 & 0.37 & 0.119298 & 2.4 \\
\hline $\begin{array}{l}\text { public } \\
\text { administration } \\
\text { and military } \\
\text { security; } \\
\text { social security }\end{array}$ & 0.16 & 6.8 & 2.36 & 9.3 \\
\hline $\begin{array}{l}\text { activities in } \\
\text { the field of } \\
\text { health and } \\
\text { social services }\end{array}$ & 0.21 & 1.93 & 0.54 & 2.7 \\
\hline
\end{tabular}




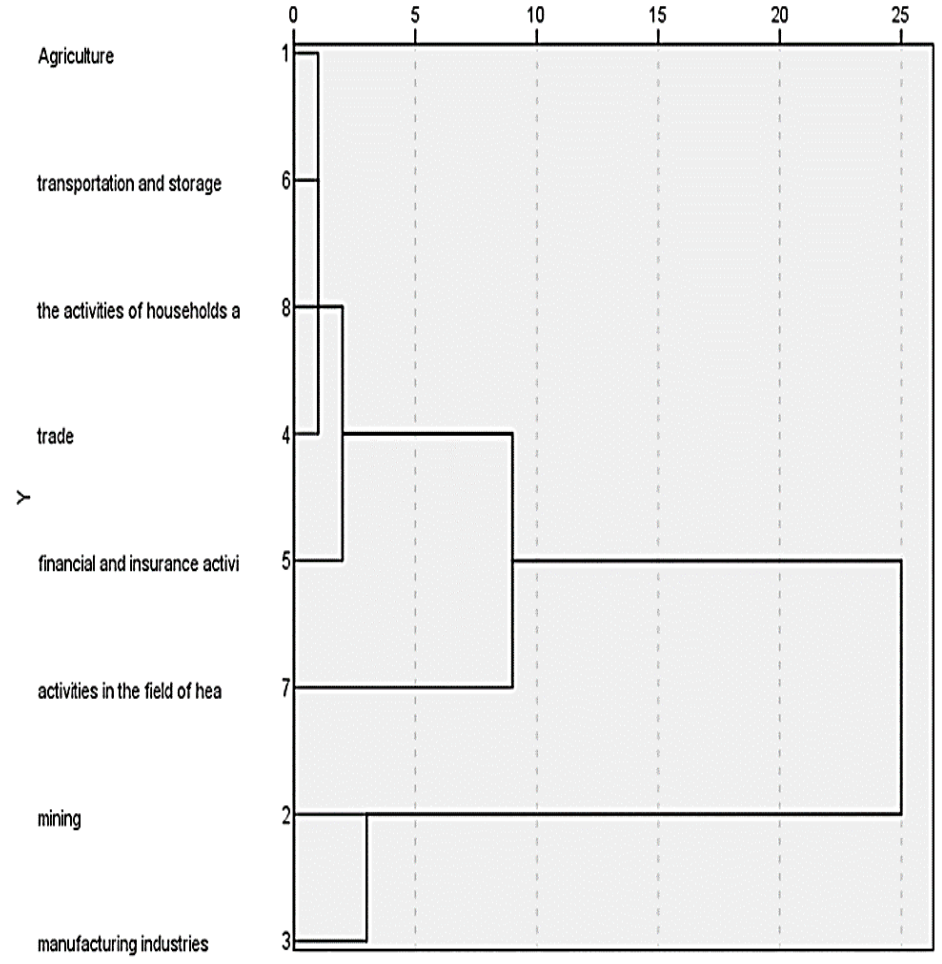

Figure 2. Dendrogram using the intragroup data method.

The data presented on the dendrogram demonstrate the main regularities in the formation of clusters located at a relatively large distance from each other. Interpretation of the results of hierarchical analysis demonstrates the need to create two clusters.

Having carried out the final stage of cluster analysis by the k-means method, the values of the final centers of the clusters were obtained (Table 6), as well as the belonging of the analyzed types of economic activities to clusters characterizing the influence of the studied externalities caused by the "blockchainization" of the economic environment on the gross value added growth. As a result, Table 7 shows the grouping of the studied types of economic activity, in accordance with the generalizing signs of the GVA growth as a result of sensitivity to the analyzed factors $V_{\text {trades }}, V_{\text {finresults, }} V_{\text {transactions. }}$

Table 6. Final centers of clusters.

\begin{tabular}{|l|c|c|}
\hline \multicolumn{1}{|c|}{ Factors } & \multicolumn{2}{c|}{ Cluster } \\
\cline { 2 - 3 } & $\mathbf{1}$ & $\mathbf{2}$ \\
\hline $\mathrm{V}_{\text {trades }}$ & 0.0288 & 0.289 \\
\hline $\mathrm{V}_{\text {finresults }}$ & 0.7069 & 6.5259 \\
\hline $\mathrm{V}_{\text {transactions }}$ & 0.0641 & 0.1129 \\
\hline
\end{tabular}


Table 7. Belonging of the analyzed types of economic activities to clusters characterizing the influence of the studied externalities caused by the "blockchainizatoin" "of the economic environment on the GVA growth in rubles.

\begin{tabular}{|l|c|}
\hline \multicolumn{1}{|c|}{ Economic activity } & Cluster belonging \\
\hline agriculture & 1 \\
\hline mining & 2 \\
\hline manufacturing industries & 2 \\
\hline trade & 1 \\
\hline financial and insurance activities & 2 \\
\hline transportation and storage & 1 \\
\hline $\begin{array}{l}\text { activities in the field of health and } \\
\text { social services }\end{array}$ & 1 \\
\hline $\begin{array}{l}\text { the activities of households as } \\
\text { employers; undifferentiated activities } \\
\text { of private households for the } \\
\text { production of goods and services for } \\
\text { their own consumption }\end{array}$ & 1 \\
\hline
\end{tabular}

\section{Summary}

The implemented assessments demonstrate the formation of two key clusters that unite the sectors of the Russian economy in terms of the degree of influence on them by externalities caused by the integration of blockchain technologies into the socioeconomic environment. The first, the broadest, cluster includes types of economic activities characterized by a moderate response to the processes of "blockchainization", the second includes sectors of the economy that demonstrate a very noticeable sensitivity to the integration of the studied technologies into the ecological environment (manufacturing, mining, agriculture). The main distinguishing characteristic of the sectors of the economy belonging to the second cluster group is a high level of response to changes in the financial results of credit institutions caused by the processes of "blockchainization". In addition, these sectors of the economy demonstrate significant sensitivity to changes in the processes of socialization of stock markets under the pressure of blockchain technologies. Apparently, this is due to the fact that economic entities of these types of economic activities are very strongly integrated into the system of stock markets, and therefore react extremely positively to the growth of exchange trading activity. At the same time, these sectors show a less noticeable reaction to the transformation of the institutional environment caused by the transition of the payment system to the crypto environment. This is most likely due to their lower capital turnover ratios.

\section{Conclusion}

In general, despite the heterogeneous degree of response to penetration into the system of economic processes, the analyzed sectors of the economy demonstrate an overwhelmingly positive reaction to digitalization in the form of diffusion of blockchain technologies (in the context of the studied areas). 


\section{Acknowledgements}

The study was supported by a grant from the Russian Science Foundation (project No. 1918-00202).

\section{References}

1. E. A. Pekhtereva, Economic and social problems of Russia, 1(37), 71 (2018) (2018)

2. R. K. Nurmukhametov, Financial analytics: problems and solutions 11, 2(344), 179 (2018)

4. H. Vranken, Current Opinion in Environmental Sustainability, 28, 1 (2017)

5. K. J. Kim, S. P. Hong, Int. J. of Security and its Application, 10(11), 201 (2016)

6. A. F. Bariviera, M. J. Basgall, W. Hasperué, M. Naiouf, Physica A 484, 82 (2017)

7. L. Cocco, G. Concas, M. Marchesi, J. of Economic Interaction and Coordination, 12(2), 345 (2017)

8. G. Pieters, S. Vivanco, Information Economics and Policy, 39, 1 (2017)

9. Federal State Statistics Service of the Russian Federation, https://rosstat.gov.ru/

10. M. R. Safiullin, A. A. Abdukaeva, L. A. Elshin, M.V. Savushkin, University Bulletin, 7, 154 (2020)

11. M. R. Safiullin, R. T. Burganov, L. A. Elshin, A. A. Abdukaeva, Theoretical and Applied Economics, 3, 105 (2020)

12. N. G. Borisova, M. F. Grigoriev, L. Yu. Dragileva, L. A. Elshin, L. A. Zbinyakova, A.V. Ivanov, N. R. Izhguzina and et al., Factors of sustainable development of Russian regions (Novosibirsk, 2015) 